GRASAS Y ACEITES 70 (2)

April-June 2019, e298

ISSN-L: 0017-3495

https://doi.org/10.3989/gya.0569181

\title{
Chemical characterization, fatty acid profile and antioxidant activity of Gustavia macarenensis fruit mesocarp and its oil from the Amazonian region of Ecuador as an unconventional source of vegetable oil
}

\author{
J.J. Reyes Mera ${ }^{\mathrm{a}}$, R. Abreu-Naranjo ${ }^{\mathrm{a}, \varpi}$, J.M. Alvarez-Suarez ${ }^{\mathrm{b}}$ and D. Viafara ${ }^{\mathrm{a}}$ \\ ${ }^{a}$ Departamento de Ciencias de la Vida, Universidad Estatal Amazónica (UEA), Vía Tena km 2 1⁄2, Puyo, Pastaza, Ecuador \\ ${ }^{b}$ Facultad de Ingeniería y Ciencias Agropecuarias (FICA). Grupo de Investigación en Biotecnología Aplicada a Biomedicina \\ (BIOMED). Universidad de Las Américas. José Queri y Ave. de los Granados, Quito, Ecuador \\ Corresponding author: reinier.abreu@gmail.com
}

Submitted: 03 May 2018; Accepted: 28 September 2018; Published online: 8 February 2019

SUMMARY: To our knowledge, this study is the first to report on the nutritional characterization, bioactive compounds and antioxidant activity of Amazonian G. macarenensis fruit. The fatty acid profile was determined using a high performance liquid chromatography analysis. The total phenolic content and antioxidant activity were determined using Folin Ciocalteu's method and by radical scavenging activity, respectively. Moreover, a cluster analysis was carried out in order to classify the G. macarenensis fruit oil according to its fatty acid profile. Seven Fisher linear discriminant functions were obtained from the discriminant analysis. These models allow one to classify new fruits on the basis of their fatty acid profile. A high value for total lipids was obtained (53.57\%). Its main components were palmitic and oleic acid. The TPC value (156.49 $\pm 2.62 \mathrm{mg} \mathrm{GAE} / \mathrm{Kg}$ of oil) obtained from the G. macarenensis fruit pulp oil is higher than what was reported for some olive oil and Brazilian mango oil varieties.

KEYWORDS: Antioxidant activity; Cluster analysis; Edible oils; Fatty acid profile; Gustavia macarenensis

RESUMEN: Caracterización química, perfil de ácidos grasos y actividad antioxidante del mesocarpio de la fruta Gustavia macarenensis y su aceite de la región amazónica de Ecuador como fuente no convencional de aceite vegetal. Hasta donde sabemos, este estudio sería el primero sobre la caracterización nutricional, los compuestos bioactivos y la actividad antioxidante de la fruta amazónica G. macarenensis. El perfil de ácidos grasos se determinó mediante análisis de cromatografía líquida de alta resolución. El contenido fenólico total y la actividad antioxidante se determinaron utilizando el método de Folin Ciocalteu y la medida de la actividad de eliminación de radicales, respectivamente. Además, se realizó un análisis de conglomerados para clasificar el aceite de fruta G. macarenensis según su perfil de ácidos grasos. Se obtuvieron siete funciones discriminantes lineales de Fisher a partir del análisis discriminante. Estos modelos permiten clasificar frutas nuevas en función de su perfil de ácidos grasos. Se obtuvo un alto valor para el total de lípidos $(53.57 \%)$. Sus componentes principales son los ácidos palmítico y oleico. El valor TPC (156.49 $\pm 2.62 \mathrm{mg}$ GAE/Kg de aceite) obtenido del aceite de pulpa de fruta de G. macarenensis es más alto que el que se reporta para algunas variedades de aceite de oliva y aceite de mango brasileño.

PALABRAS CLAVE: Aceites comestibles; Actividad antioxidante; Análisis de conglomerados; Gustavia macarenensis; Perfil de ácidos grasos

ORCID ID: Reyes JJ https://orcid.org/0000-0001-6435-0649, Abreu NR https://orcid.org/0000-0003-1048-7126, Alvarez JM https://orcid.org/0000-0001-8509-1498, Viafara D https://orcid.org/0000-0003-1376-1231

Citation/Cómo citar este artículo: Reyes JJ, Abreu NR, Alvarez JM, Viafara D. 2019. Chemical characterization, fatty acid profile and antioxidant activity of Gustavia macarenensis fruit mesocarp and its oil from the Amazonian region of Ecuador as an unconventional source of vegetable oil. Grasas Aceites 70 (2), e298. https://doi.org/10.3989/gya.0569181

Copyright: (C2019 CSIC. This is an open-access article distributed under the terms of the Creative Commons Attribution 4.0 International (CC BY 4.0) License. 


\section{INTRODUCTION}

Gustavia macarenensis Philipson is a species belonging to the Gustavia L. genus, in the Lecythidaceae A. Rich family (Jørgensen and León-Yánez, 1999). It is a native to South America, mainly found in the western part of the Ecuadorian and Peruvian Amazon basin. According to the records of the Missouri Botanical Garden (Tropicos.org) web site, this plant can grow at altitudes ranging from 450 to 1200 masl. In Pastaza Province, Ecuador, it can be found between 700 and 830 masl. G. macarenensis is a tree that grows to $25 \mathrm{~m}$ tall, with a dense, globule to obviate crown, its leaf bearing branches are $5-10 \mathrm{~mm}$ in diameter and sylleptic branches are often present. The bark is light grey and almost smooth. Leaf blades are elliptic, oblanceolate, glabrous or coriaceous and $15-61 \times 6-19 \mathrm{~cm}$ in size. Its petioles are $10-70 \times 2-4 \mathrm{~mm}$ thick. It has supra foliar inflorescences, sometimes at the end of sylleptic branches, racemes and tan-to-rusty tomentose leaves, with 3-6 flowers (Prance and Mori, 1979). The ripe fruits have a delicious flavor and Amazon natives consume them fresh, in juices or as oil which is traditionally extracted by boiling the mesocarp. Its mesocarp has a smooth, buttery texture like avocado and has a flavor similar to peanuts. The indigenous communities use the pulp as a purgative and the infusion of the bark is used to stop uterine haemorrhaging and the fresh seeds fight dysentery and sinusitis (Prance and Mori, 1979, García et al., 2011).

According to Chow (2007), the potential of lipid material from fruits and fruit by-products is enormous and should be investigated. The application of oil for nutritional, industrial, and pharmaceutical purposes is determined by its fatty acid composition. No oil from a single raw material has been found to be suitable for all purposes, since oils from diverse natural resources have different lipid profiles. It is for this reason that the study of new raw materials for vegetable oil production is so important (Kamel and Kakuda, 2007). New sources of vegetable oil could supplement traditional supplies or even replace some imports. Also, fruits are well-known as a good source of dietary fiber, minerals, vitamins and bioactive compounds (Charoenkiatkul et al., 2016). Many fruits are rich in phenolic compounds, vitamins, nutrients and other bioactive compounds with great health benefits (Charoenkiatkul et al., 2016). Phenolic compounds are secondary metabolites, which are present in fruits and vegetables (SrdićRajić and Konić Ristić, 2016). The major polyphenol classes are phenolic acids, flavonoids, and procyanidins. Several studies have demonstrated a close relationship between these compounds and their antioxidant potential (Chang et al., 2007; Muhtadi et al., 2015; Ramos et al., 2015; Javanmardi et al., 2003).

The phenolic compounds' beneficial effect on the antioxidant capacity of fats and oils is well documented (Owen et al., 2000; Pokorny et al., 2001; Radice et al., 2014; Polychniatou and Tzia, 2018). Many papers have focused on the antioxidant effect of phenolic compounds present in fruits and fruitbased oils, although ascorbic acid, carotenoids and tocopherols also contribute to their antioxidant activity. Antioxidant compounds in food play an essential role as a factor in protecting health. Scientific evidence suggests that antioxidants reduce the risk of chronic diseases including cancer and heart disease. Principal sources of naturally-occurring antioxidants are whole fruits, vegetables and grains (Mishra et al., 2010).

Some species of the Lecithidaceae family such as Gustavo augusta L., Gries neuberthii Macbr and Theobroma bicolor, native to the Peruvian Amazon, comprise an important percentage of antioxidant activity inhibition, proven with in vitro evaluation and compared to synthetic BHT 2,3,4 (García et al., 2011). However, little is known about the data concerning the chemical-physical composition, fatty acid profile and antioxidant activity of the mesocarp and its oil obtained from the $G$. macarenensis fruit.

The aim of this study was to determine the physical and chemical characteristics of the G. macarenensis fruit mesocarp, as well as the fatty acid composition, total phenolic content and antioxidant activity of the oil obtained from the fruit pulp. Additional objectives were to demonstrate the species' potential as an unconventional source of plant oil and to contribute further knowledge of the nutritional value of the species in general.

\subsection{MATERIALS AND METHODS}

\subsection{Collection of fruits and sample preparation}

The Gustavia macarenensis fruits were collected from the Amazon rainforest in Pastaza, Ecuador in October 2017 and identified by the botanist Dr. David Neil in the Herbarium of the Universidad Estatal Amazónica (ECUAMZ), Puyo, Ecuador. A total of 20 randomly chosen fruits (about $5.2 \mathrm{~kg}$ of ripe fruits ripe enough for consumption, physically undamaged and uniformly shaped, well-sized with good color) were collected and the fruit pulp $(1.1 \mathrm{~kg})$ was manually separated. Before the extraction process, the fruit pulp was dried in a stove at a temperature of $45^{\circ} \mathrm{C}$ for 48 hours. Later, it was ground in a mill until particle sizes of $1 \mathrm{~mm}$ were achieved, in accordance with the ASTM-E1757-01 (2007) using a set of Tyler mesh sieves. 


\subsection{Characterization of the Gustavia macarenensis fruit pulp and its oil}

The fruit pulp was characterised using proximate analysis; while the physical-chemical properties were determined for the pulp oil. The information regarding these parameters is very useful in determining the quality of the raw material as a potential source of vegetable oil in the future. Physical-chemical determinations were performed according to the standardized methods proposed by the Official Methods of Analysis of AOAC International. The standards used in the study are summarized in Table 1.

\subsection{Oil extraction}

The Soxhlet Method was selected as our extraction technique, using $\mathrm{n}$-hexane as solvent, and was carried out according to the method reported by Pereira et al., (2017). For each $30 \mathrm{~g}$ extraction of fruit pulp, the cellulose was wrapped in cartridges and placed in the Soxhlet apparatus. $250 \mathrm{~mL}$ of solvent were added, and the system was heated to boiling point. Reflux was held for $4 \mathrm{hrs}$. After extraction, the solvent was eliminated in a rotary vacuum evaporator (YAMATO, Model: RE200A, Japan) at $60^{\circ} \mathrm{C}$ and $500 \mathrm{~mm} \mathrm{Hg}$. The extraction yield was calculated as the ratio between the mass of oil obtained and the mass of raw material used. Oil samples were stored at $-5{ }^{\circ} \mathrm{C} \pm 2{ }^{\circ} \mathrm{C}$ and protected from light prior to analysis.

\subsection{Fatty acid profiles of the fruit pulp oil}

The fatty acid profile in the oil sample was determined by High Performance Liquid Chromatography (HPLC), using a Waters instrument, model: Alliance 2695, equipped with a column symmetry C18, $5 \mu \mathrm{m}$, $250 \times 4.6 \mathrm{~mm}$. In this analysis, the MMQ-HPLC- 09 standard was employed.

\subsection{Extraction of phenolic compounds}

The extraction of the phenolic compounds from oil samples was carried out by liquid - liquid extraction using methanol as a solvent, according to the procedure described by Baiano et al., (2009) with some modifications. $2 \mathrm{~mL}$ of a methanol:water solution (70:30, v/v) and $2 \mathrm{~mL}$ of hexane were added to $3 \mathrm{~g}$ of oil and mixed with a Vortex for $10 \mathrm{~min}$. The hydroalcoholic phase containing phenolics was separated from the oily phase by centrifugation $\left(6000 \mathrm{rpm}, 4^{\circ} \mathrm{C}\right.$, $10 \mathrm{~min})$. The hydroalcoholic phases were collected and submitted to another centrifugation (13000 rpm, at room temperature, $4 \mathrm{~min}$ ). Finally, hydroalcoholic extracts were recovered with a syringe and then filtered through a $0.45 \mu \mathrm{m}$ nylon filter before analysis.

\subsection{Determination of total phenolic content (TPC)}

The TPC was determined using the Folin Ciocalteu's reagent method (Singleton et al., 1999). Approximately $0.1 \mathrm{~mL}$ of the oil sample was mixed with $0.5 \mathrm{~mL}$ of Folin-Ciocalteau reagent and subsequently $7 \mathrm{~mL}$ of distilled water were added. The mixture was left standing in the dark for 5 min at room temperature. Afterwards, $1.5 \mathrm{~mL}$ of sodium carbonate solution was added and the mixture was left at room temperature for another $2 \mathrm{hrs}$. The absorbance was measured at a wavelength of $765 \mathrm{~nm}$ in a Genesys 10 UV Scanning spectrophotometer model. Gallic acid was used as a standard to produce the calibration curve and TPC was expressed as $\mathrm{mg}$ of Gallic acid equivalents (GAE) per $\mathrm{Kg}$ of oil (mg GAE/Kg of oil).

\subsection{Determination of lipophilic antioxidant compounds (tocopherols, total chlorophylls and carotenoids)}

Lipophilic antioxidant compounds were determined using a HPLC system (Shimadzu Corp., Kyoto, Japan) equipped with a Waters 600

TABLE 1. Summary of the methods used for the characterization of the mesocarp and its oil obtained from G. macarenensis

\begin{tabular}{|c|c|c|c|}
\hline \multicolumn{2}{|c|}{ Fruit pulp } & \multicolumn{2}{|c|}{ Pulp oil } \\
\hline Component & Standard & Component & Standard \\
\hline Total lipids & AOAC 920.39 & Specific gravity & AOCS Cc 10c-95 (09) \\
\hline Crude fibre & AOAC 935.53 & Acid value & AOCS Cd 3d-63 (09) \\
\hline Crude protein & AOAC 954.01 & Free fatty acids & AOCS Ca 5a-40 (09) \\
\hline Carbohydrates & By difference & Saponification value & AOCS Cd 3-25 (11) \\
\hline Total Minerals & AOAC 923.03 & Unsaponifiable Matter & AOCS Ca-40 (11) \\
\hline Moisture & AOAC 925.10 & Peroxide value & AOCS Cd 8b-90 (11) \\
\hline \multirow[t]{3}{*}{ Energy value } & (Moreiras et al., 2013) & Iodine value & AOCS Cd 1-25 (93) \\
\hline & & Refractive index $\left(25^{\circ}\right)$ & AOCS Cc 7-25 (09) \\
\hline & & Moisture & AOCS Ca 2f-93 (09) \\
\hline
\end{tabular}


controller and a Waters 996 photodiode array (PDA) detector set at an absorbance of $294 \mathrm{~nm}$ and equipped with a C18 column $(150 \times 4.6 \mathrm{~mm}, 3 \mu \mathrm{m}$; Phenomenex) as the stationary phase. Elution was performed with acetonitrile-methanol $(90: 10, \mathrm{v} / \mathrm{v})$ as eluent mixture at a flow rate of $0.8 \mathrm{~mL} / \mathrm{min}$ and the run time was $35 \mathrm{~min}$. Samples (five milligrams) were diluted with $200 \mu \mathrm{L}$ of chloroform and $790 \mu \mathrm{L}$ of an acetonitrile-methanol (50:50, v/v) mixture and injected manually into the HPLC system. $\alpha$ - tocopherols $(1-40 \mu \mathrm{g} / \mathrm{mL}, \mathrm{y}=2.347 \mathrm{x}+4.8353$, $\left.\mathrm{R}^{2}=0.9821\right)$ in acetone were used to produce the calibration curve. For total chlorophyll and carotenoid determination, a solution of $5 \%$ of the oil in acetone $(80 \%)$ was prepared and estimated spectrophotometrically at two different wavelengths (464 $\mathrm{nm}$ for carotenoids and $669 \mathrm{~nm}$ for chlorophylls) using a Synergy ${ }^{\mathrm{TM}} 2$ Multi-Detection Microplate. $\beta$-carotene $(0.25-4 \mathrm{mg} / \mathrm{mL}, y=$ $\left.0.1145 \times+0.0235, \mathrm{R}^{2}=0.9978\right)$ in acetone to produce the calibration curve, while the quantification of total chlorophylls was calculated as previously described (Porra, 2002).

\subsection{Total antioxidant capacity}

Radical scavenging activity was studied using 1,1-diphenyl-2-picrylhydrazyl free radical (DPPH) as previously reported by Thaipong et al., (2006). $1.5 \mathrm{~mL}$ of oil extract was mixed with $1.5 \mathrm{~mL}$ of a $0.2 \mathrm{~m}$ Mmethanolic DPPH solution. After an incubation period of $30 \mathrm{~min}$ at $25^{\circ} \mathrm{C}$, the absorbance at $515 \mathrm{~nm}$ was measured. A Trolox calibration curve was used and data were expressed in Trolox equivalents (mmol of TE/Kg). DPPH scavenging activity $(\%)=\left[1-\left(\left(\mathrm{Ab}_{\text {sol }}-B_{2}\right) / B_{1}\right)\right] \times 100$ where $\mathrm{Ab}_{\text {sol }}, B_{1}$ and $B_{2}$ are the absorbance of the sample, sample blank and oil extract blank, respectively. The values are expressed as the mean of three $\mathrm{IC}_{50}$ values (concentration causing 50\% inhibition) of each sample determined graphically.

\subsection{Statistical analyses}

Statistical analyses were performed using IBM SPSS Statistics v. 24. Data are reported as a mean value \pm standard deviation (SD) for three measurements $(n=3)$. In addition, a cluster analysis was carried out in order to classify the G. macarenensis fruit oil according to its fatty acid profile. Ward's method was used for the formation of the clusters and the squared Euclidean distance for the calculation of the intervals between the groups. Then, a discriminant analysis was applied for the validation of the cluster. In this study, the fatty acid composition obtained from the mesocarp of 35 fruits previously reported by Chow (2007) were used. (See supplementary material).

\section{RESULTS AND DISCUSSION}

\subsection{Physicochemical characteristics of the G. macarenensis fruit pulp and of the oil from its mesocarp}

The outer appearance of the G. macarenensis fruit and the appearance of its different parts are shown in Figure 1.

The fruit ( $G$. macarenensis) is of medium size and the collected samples had an average weight of $258 \mathrm{~g}$. The rind is tough and thick and is lilac to brownish in color mixed with some green shades. When ripe, the fruit is easily split and usually contains four to six seeds embedded in a yellowish edible pulp which is soft and sweet with an exquisite odor much liked by the local people of the Ecuadorian Amazonian basin.

The proximate analysis of the fruit pulp and the physical-chemical properties ofthe oil extracted from the mesocarp of G. macarenensis are summarized in Table 2.

As can observed in Table 2, the G. macarenensis fruit mesocarp contains a high value for total lipids $(53.57 \%)$, which is uncommon for fruit pulp, as it usually contains very low levels of lipid material $(0.1$ to $1.0 \%)$. A few notable exceptions are avocado, palm fruit and olives, which range from $6.5-25.5 \%, 8-74 \%$ and $35-70 \%$, respectively (Kamel and Kakuda, 2007). These are recognized as being sources of natural oils and as having several applications. In addition, G. macarenensis fruit mesocarp's fat, crude fiber and crude protein values are higher than those reported by Devalaraja et al., (2011) for durian (Durio zibethinus) fruit pulp (fat $(5.33 \%)$, crude fiber $(3.1 \%)$, protein $(1.47 \%)$ ), which is considered to be a fruit with high nutritional value. The carbohydrate content is similar to that which was reported by Andrade et al., (2001) for the pulp of the Amazonian Annona squamosa fruit (20.95\%) and lower than that of durian $(27 \%)$.

Most of the results from the physical-chemical analyses performed on fruit pulp oils comply with the Codex Alimentarius International Food Standards established for virgin palm oils, which are found amongst the most commercialized vegetable oils worldwide (Commission, 2008). The acid value was determined at $3.56 \mathrm{mg} \mathrm{KOH} / \mathrm{g}$ oil, which is below the maximum value suggested by CODEX STAN 210 as an essential quality parameter $(10.0 \mathrm{mg} \mathrm{KOH} / \mathrm{g})$. This parameter is related to oil degradation caused by hydrolysis (Pereira et al., 2017). Moreover, the values for saponification, unsaponifiable matter and density are reasonably inside the range defined for palm oil by Codex Stan 210: 190-209 mg KOH/g oil $\leq 1.2 \%$ and $0.891-0.899 \mathrm{~g} / \mathrm{mL}$, respectively. The iodine value of the G. macarenensis oil was lower than $50-55$, which is the range reported for palm oil. 

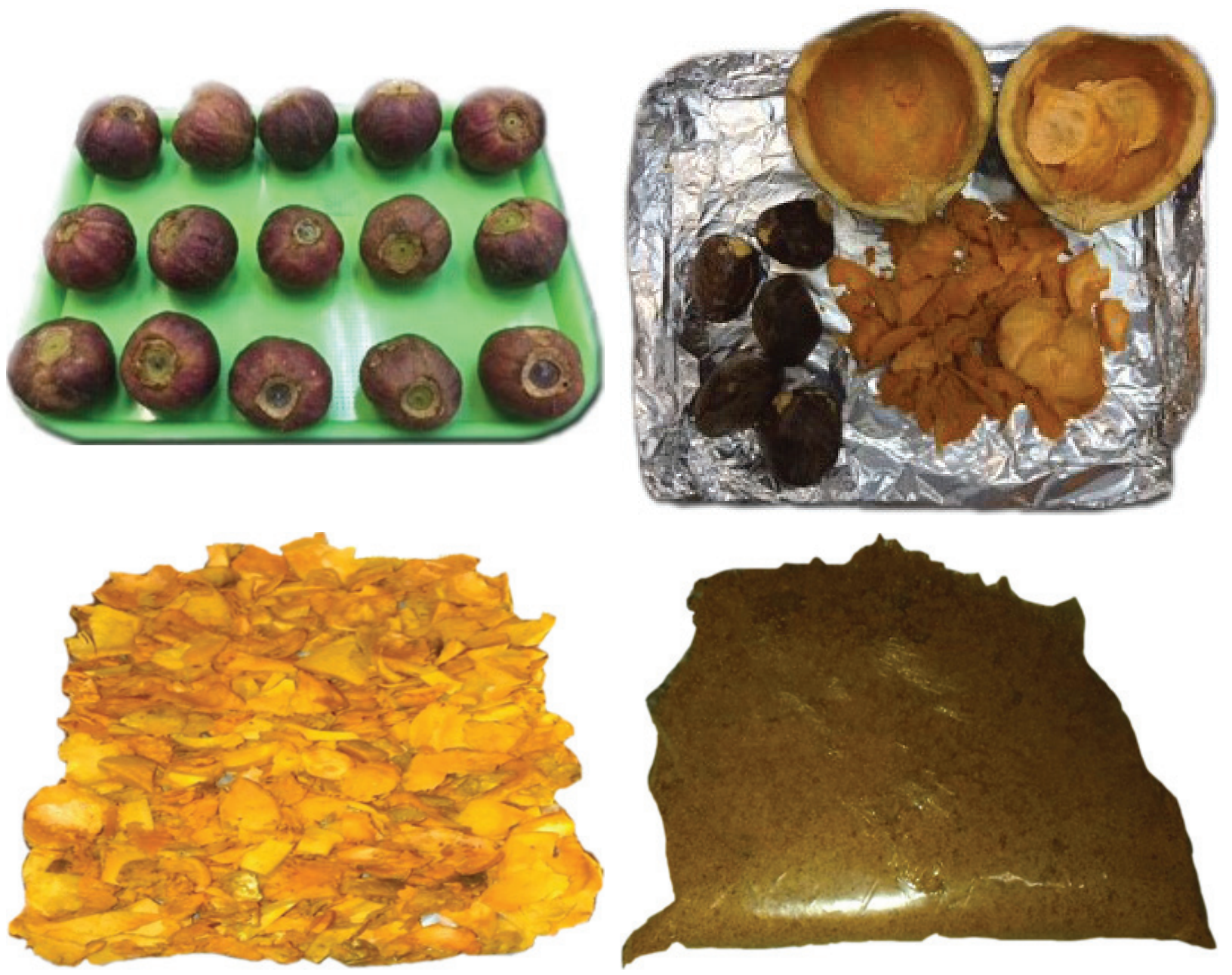

FIGURE 1. The outer appearance of the Gustavia macarenensis fruit and its different parts (Upper right: G. macarenensis fruit; upper left: husk, seed and mesocarp; lower left and right: unground mesocarp dried at $45^{\circ} \mathrm{C}$; lower right: mesocarp dried and $45^{\circ} \mathrm{C}$ and ground to $1 \mathrm{~mm}$ particle size).

TABLE 2. Physical-chemical characteristics of the G. macarenensis fruit pulp and of the oil from its mesocarp

\begin{tabular}{|c|c|c|c|}
\hline \multicolumn{2}{|c|}{ Proximate analysis of fruit pulp } & \multicolumn{2}{|c|}{ Physical-chemical properties of oil } \\
\hline Component & Value \pm SD & Component & Value \pm SD \\
\hline Total lipids (\%wt) & $53.57 \pm 3.05$ & Density $\left(\mathrm{g} / \mathrm{mL}\right.$ at $\left.25^{\circ} \mathrm{C}\right)$ & $0.90 \pm 0.00$ \\
\hline Crude fibre (\%wt) & $11.53 \pm 0.59$ & Acid value (mg KOH/g) & $3.56 \pm 0.05$ \\
\hline Crude protein (\%wt) & $12.82 \pm 0.10$ & Free fatty acid (g Oleic Ac. /100 g) & $1.80 \pm 0.02$ \\
\hline Carbohydrates (\%wt) & $19.73 \pm 2.18$ & Saponification value (mg KOH/g) & $186.5 \pm 0.77$ \\
\hline Total Minerals (\%wt) & $2.34 \pm 0.04$ & Unsaponifiable Matter (\%wt) & $0.79 \pm 0.01$ \\
\hline Moisture (\%) & $55.77 \pm 0.11$ & Peroxide value (mEq. peroxide/Kg) & $2.14 \pm 0.01$ \\
\hline Ash (\%wt) & $2.34 \pm 0.03$ & Iodine value $(\mathrm{g} / 100 \mathrm{~g})$ & $48.05 \pm 0.31$ \\
\hline \multirow[t]{2}{*}{ Energy value (Kcal/100g) } & $626.25 \pm 16.1$ & Refractive index $\left(25^{\circ} \mathrm{C}\right)$ & $1.46 \pm 0.00$ \\
\hline & & Moisture (\%) & $2.54 \pm 0.03$ \\
\hline
\end{tabular}

All the \%wt are expressed on a dry basis. Three measurements for all analyses $(n=3)$. 
According to Chow (2007), the iodine value is proportional to the degree of unsaturation, which is in accordance with the unsaturation content of mesocarp oil of the M. macarenensis fruit, similar to palm oil.

\subsection{Fatty acid composition and classification of the G. macarenensis oil obtained from its mesocarp}

As can be observed in the analysis of the fatty acid profile (Table 3), the oil extracted from G. macarenensis mesocarp has palmitic and oleic acid as its main components. This explains the fact that it has a similar iodine value to that of palm oil (Elaeis guineensis), which usually has a range of 36 to $44 \%$ of oleic acid amongst its major unsaturated acids (Commission, 2008). In third place, one finds linoleic acid, although in lower quantities than the two aforementioned acids, whilst stearic, $\alpha$-linolenic, eicosatrienoic, palmitoleic and margaric acids were present in small quantities of less than 4\%. As described above, the statistical classification method known as the cluster analysis was used for making quantitative comparisons between the fatty acid compositions of 35 fruits and the composition of G. macarenensis oil. Figure 2 shows the dendrogram obtained from the cluster analysis of 36 fruits by Ward's Method based on the fatty acid composition data, in which one can see the formation of 7 groups clearly defined based on their profiles. Notably, G. macarenensis was related to two more fruits: Durio zibethinus (Durian) and Buchanania lanzan (Chironji fruit).

The durian is an important economic fruit crop in several Southeast Asian countries, where it is known as the king of fruits (Ho and Bhat, 2015). In a few years, it has gone from being a curiosity to an important horticultural crop beyond the regional market, mainly due to the fact that it can be used in so many areas including the medical field and food industry. The fruit of this tree is considered a good source of fatty acids which has multiple benefits for human health (Mariod et al., 2017).

On the other hand, although less studied, is the Chironji fruit, whose kernel oil is used as a substitute for olive and almond oils, while the kernels are commonly used in sweet meats as a substitute for almond kernels (Hemavathy and Prabhakar, 1988). Other studies have reported on the immunostimulant and astringent properties of the dried fruits of B. Lanzan (Puri et al., 2000). These fruits are also known to possess antioxidant and antiinflammatory activities (Shailasree et al., 2012). Pattnaik et al., (2013) carried out pharmacological studies on B. lanzan in wound healing and concluded that it has significant potential. However, it is too early to know if the G. macarenensis has some of these properties and further studies into its pharmacological properties and a phytochemical analysis are necessary.

Based on the application of the discriminant analysis for validating the cluster, it was found that $97.2 \%$ were classified correctly. Seven Fisher linear discriminant functions were obtained from the discriminant analysis. These models allow one to classify new fruits on the basis of their fatty acid profile and to determine which of the seven groups they belong to. In addition, it was concluded that of the seven fatty acids considered, 5 were highly significant with a p-value of < 0.01 (16: 0, 16: 1, 18: 1, 18: 2, 18: 3). 14: 0 was significant ( $p$-value $<0.05$ ), while 18: 0 was not significant in the formation of groups with a p-value of 0.619 , much greater than 0.05 .

TABLE 3. Fatty acid profile (\%) of G. macarenensis, D. zibethinus and B. lanzan oils

\begin{tabular}{lccc}
\hline & G. macarenensis & D. zibethinus & B. lanzan \\
\cline { 3 - 4 } Fatty Acid & & Source: (Chow, 2007) \\
\hline C14:0 (Myristic) & 0.10 & 0.5 \\
C15:0 (Pentadecanoic) & 42.89 & 39.8 & \\
C16:O (Palmitic) & 0.37 & 8.5 & 34.4 \\
Cis-C16:1(n-9) (Palmitoleic) & 0.55 & & \\
C17:0 (Margaric) & 3.72 & 0.8 & 2.0 \\
C18:O (Stearic) & 43.30 & 45.8 & 62.3 \\
C18:1(n-9) (Oleic) & 6.48 & 1.8 & 1.2 \\
C18:2 (n-6) (Linoleic) & 1.77 & 2.7 & 0.2 \\
C18:3(n-3) ( $\alpha$-Linolenic) & 0.05 & & \\
C20:0 (Arachidic) & 0.76 & & 36.4 \\
cis,cis,cis-8,11,14 C20:3 (Eicosatrienoic) & 47.33 & 41.1 & 63.7 \\
Total Saturated & 52.67 & 58.8 & \\
Total Unsaturated & & & \\
\hline
\end{tabular}




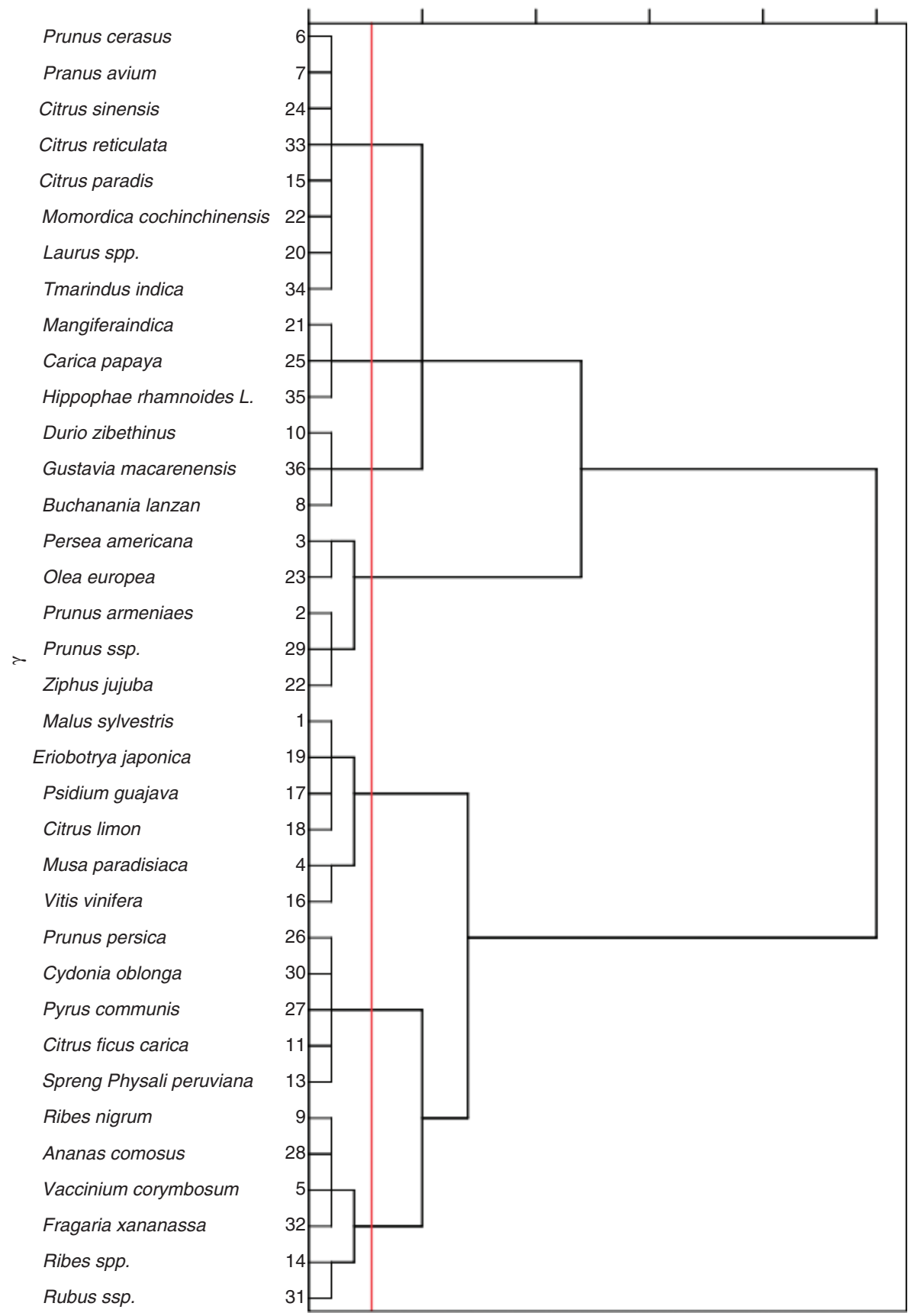

FIGURE 2. Dendrogram obtained from the cluster analysis of 36 fruits by Ward's method for the classification of G. macarenensis based on its fatty acid composition.

The linear models can be expressed as follow:

$$
\begin{aligned}
D_{1}= & -29.724+0.057 X_{14: 0}+1.517 X_{16: 0}+0.151 X_{16: 1} \\
& +0.182 X_{18: 1}+0.42 X_{18: 3} \\
D_{2}= & -51364+1.12 X_{14: 0}+0.564 X_{16: 0}+0.038 X_{16: 1} \\
& +1.377 X_{18: 1}-0.341 X_{18: 3} \\
D_{3}= & -15,364-0,349 X_{14: 0}+0,309 X_{16: 0}+0,274 X_{16: 1} \\
& +0,252 X_{18: 1}+0,815 X_{18: 3}
\end{aligned}
$$

$$
\begin{aligned}
D_{4}= & -25,342+0,462 X_{14: 0}+1,097 X_{16: 0}+0,297 X_{16: 1} \\
& +0,629 X_{18: 1}+0,19 X_{18: 3} \\
D_{5}= & -60,915+0,094 X_{14: 0}+1,914 X_{16: 0}-0,043 X_{16: 1} \\
& +0,996 X_{18: 1}-0,208 X_{18: 3} \\
D_{6}= & -15,521+0,613 X_{14: 0}+0,560 X_{16: 0}+0,052 X_{16: 1} \\
& +0,659 X_{18: 1}-0,155 X_{18: 3} \\
D_{7}= & -133,154+13,009 X_{14: 0}+0,642 X_{16: 0}+7,395 X_{16: 1} \\
& +0,433 X_{18: 1}+0,474 X_{18: 3}
\end{aligned}
$$


where:

$D_{x}$ : discriminant functions.

$D_{x: D}$ : composition of the corresponding fatty acid (\%).

\subsection{Total polyphenol contents, lipophilic antioxidant compounds and total antioxidant capacity}

Table 4 presents the total polyphenol contents, lipophilic antioxidant compounds and total antioxidant capacity of the $G$. macarenensis fruit pulp oil. The TPC value obtained for the G. macarenensis fruit pulp oil was higher than that determined by Tanilgan et al., (2007) in the olive oil varieties of Gemlik, Kilis, Uslu, Tirilye and Ayvalik (from 22.5 to $97.1 \mathrm{mg} \mathrm{GAE} / \mathrm{Kg}$ ). Furthermore, the phenolic contente stimated for the G. macarenensis oil is higher than the values reported by Ribeiro et al., (2008) for Brazilian mango seeds and peels (Mangifera indica $\mathrm{L}$. variety Ubá), which were 82.54 and $57.24 \mathrm{mg}$ GAE/Kg, respectively. According to the same authors, these are 4.6 and 7.3 times higher than those found in the Ubá pulp, respectively.

However, the values obtained in this study for carotenoids are similar to the contents reported for the Brazilian mango varieties Tommy Atkins, Palmer and Ubá (from 2.5 to $2.6 \mathrm{mg} / \mathrm{Kg}$ ) (Rocha Ribeiro et al., 2007). Carotenoids have been recognized as a powerful antioxidant (Nwaichi et al., 2015). Dietary carotenoids are associated with health benefits, such as reducing the risk of disease, particularly skin cancer and inflammation along with fighting others cancers, cardiovascular and related disorders and those diseases related to oxidative stress (Johnson, 2002). The antioxidant activity by DPPH assay was determined for the oil from G. macarenensis pulp (see table 4). This value is low in comparison to other fruits. This could be due to different causes, for instance degree of fruit maturity, storage and the conditions of the technique employed.

\section{CONCLUSIONS}

To the best of our knowledge, this study is the first report about the nutritional characterization, bioactive compounds and antioxidant activity of the

TABLE 4. Total polyphenol contents, lipophilic antioxidant compounds and total antioxidant capacity of $G$. macarenensis fruit pulp oil

\begin{tabular}{lr}
\hline Assay & Value \pm SD \\
\hline TPC (mg GAE/Kg of oil) & $156.49 \pm 2.62$ \\
$\alpha$-tocopherols $(\mathrm{mg} / \mathrm{Kg}$ of oil) & $90.23 \pm 2.32$ \\
Chlorophylls (mg/Kg of oil) & $5.21 \pm 0.21$ \\
Carotenoids (mg/Kg of oil) & $2.62 \pm 0.16$ \\
DPPH ( $\mu \mathrm{mol}$ of $\mathrm{TE} / \mathrm{Kg}$ of oil) & $170 \pm 2.86$ \\
\hline
\end{tabular}

Three measurements for all analyses $(n=3)$.
Amazonian G. macarenensis fruit. The data reported herein could be used for consumer nutritional education as well as for the fruit's incorporation into food composition databases. The physical-chemical analyses performed on the fruit pulp oils comply with the Codex Alimentarius International Food Standards. A high value of total lipids was obtained $(53.57 \%)$, thus G. macarenensis can be considered a good source of vegetable oil. The fatty acid profile of the oil extracted from the G. macarenensis mesocarp contains palmitic and oleic acid as its main components. Moreover, the fatty acids composition of the G. macarenensis pulp oil was compared with that of 35 fruits by means of a cluster analysis and it was concluded that it is similar to that of Durio zibethinus (Durian) and Buchanania lanzan (Chironji fruit). The TPC value $(156.49 \pm 2.62 \mathrm{mg}$ GAE/Kgof oil) obtained from the G. Macarenensis fruit pulp oil is highert than that which was reported for some olive oil and Brazilian mango varieties. However, the oil from $G$. Macarenensis presented a lower antioxidant activity (DPPH assay) than other fruits. Therefore, this suggests that other antioxidant activity assays must be applied to the oil from the G. Macarenensis pulp in order to support these results.

\section{CONFLICTS OF INTEREST}

The authors declare no conflicts of interest.

\section{ACKNOWLEDGMENTS}

This research was supported by the Universidad Estatal Amazónica, Puyo, Ecuador and the Universidad de Las Américas, Quito, Ecuador (Grant no. VET.JMA.17.05, 2017).

\section{REFERENCES}

Andrade EHA, Zoghbi MDGB, Maia JGS, Fabricius H, Marx F. 2001. Chemical characterization of the fruit of Annona squamosa L. occurring in the Amazon. J. Food Compos. Anal. 14, 227-232. https://doi.org/10.1006/jfca.2000.0968

Astm-E1757-01 2007. Standard practice for preparation of biomass for compositional analysis. https://doi.org/10.1520/ e1757-01r15

Baiano A, Gambacorta G, Terracone C, Previtali M, Lamacchia C, La Notte E. 2009. Changes in phenolic content and antioxidant activity of Italian extra-virgin olive oils during storage. J. Food Sci. 74, C177-C183. https://doi.org/ $10.1111 / \mathrm{j} .1750-3841.2009 .01072 . x$

Commission CA. 2008. Codex-Stan 210: codex standard for named vegetable oils. FAO, Rome, Italy.

Chang HC, Huang GJ, Agrawal DC, Kuo CL, Wu CR, Tsay HS. 2007. Antioxidant activities and polyphenol contents of six folk medicinal ferns used as "Gusuibu". Botanical Studies, 48, 397-406

Charoenkiatkul S, Thiyajai P, Judprasong K. 2016. Nutrients and bioactive compounds in popular and indigenous durian (Durio zibethinus Murr.). Food Chem. 193, 181-186. https://doi.org/10.1016/j.foodchem.2015.02.107

Chow CK. 2007. Fatty acids in foods and their health implications, CRC press Taylor \& Francis Group. https://doi.org/ 10.1201/9781420006902 
Devalaraja S, Jain S, Yadav H. 2011. Exotic fruits as therapeutic complements for diabetes, obesity and metabolic syndrome. Food Res. Int. 44, 1856-1865. https://doi.org/10.1016/j. foodres.2011.04.008

García D, Sotero V, Mancini D, Pavan Torres R, Mancini Filho J. 2011. Evaluación de la actividad antioxidante" In vivo" de tres frutos de la amazonía: Gustavia augusta L., Grias neuberthii Macbr y Theobroma bicolor. In spanish (Evaluation of the antioxidant activity "In vivo" of three fruits of the Amazon: Gustavia augusta L., Grias neuberthii Macbr and Theobroma bicolor). Rev. Soc. Quim. Peru, 77, 44-55.

Hemavathy J, Prabhakar JV. 1988. Lipid composition of chironji (Buchanania lanzan) kernel. J. Food Compos. Anal. 1, 366-370. https://doi.org/10.1016/0889-1575(88)90037-3

Ho LH, Bhat R. 2015. Exploring the potential nutraceutical values of durian (Durio zibethinus L.) - An exotic tropical fruit. Food Chem. 168, 80-89. https://doi.org/10.1016/j. foodchem.2014.07.020

Javanmardi J, Stushnoff C, Locke E, Vivanco JM. 2003. Antioxidant activity and total phenolic content of Iranian Ocimum accessions. Food Chem. 83, 547-550. https://doi. org/10.1016/S0308-8146(03)00151-1

Johnson EJ. 2002. The role of carotenoids in human health. Nutrition in Clinical Care 5, 56-65. https://doi. org/10.1046/j.1523-5408.2002.00004.x

Jørgensen P, León-Yánez S. 1999. Catalogue of the Vascular Plants of Ecuador. Monographs in Systematic Botany from the Missouri Botanical Garden 75, i-viii, 1-1181.

Kamel BS, Kakuda Y. 2007. Fatty acids in fruits and fruit products. Acids in Foods and Their Health Implications. 263-301. Taylor \& Francis Group.

Mariod AA, Saeed Mirghani ME, Hussein I. 2017. Chapter 30 Durio zibethinus (Durian). Unconventional Oilseeds and Oil Sources. Academic Press. https://doi.org/10.1016/ B978-0-12-809435-8.00030-5

Mishra N, Dubey A, Mishra R, Barik, N. 2010. Study on antioxidant activity of common dry fruits. Food Chem. Toxicol. 48, 3316-3320. https://doi.org/10.1016/j.fct.2010.08.029

Moreiras O, Carbajal A, Cabrera L, Cuadrado C. 2013. Tablas de composición de alimentos, Madrid, Ediciones Pirámide.

Muhtadi, Primarianti AU, Sujono TA. 2015. Antidiabetic Activity of Durian (Durio Zibethinus Murr.) and Rambutan (Nephelium Lappaceum L.) Fruit Peels in Alloxan Diabetic Rats. Procedia Food Science 3, 255-261. https://doi.org/ 10.1016/j.profoo.2015.01.028

Nwaichi E, Chuku L, Oyibo N. 2015. Profile of ascorbic acid, beta-carotene and lycopene in guava, tomatoes, honey and red wine. International Journal of Current Microbiology and Applied Sciences 4, 39-43.

Owen RW, Giacosa A, Hull WE, Haubner R, Würtele G, Spiegelhalder B, Bartsch H. 2000. Olive-oil consumption and health: the possible role of antioxidants. The Lancet Oncology 1, 107-112. https://doi.org/10.1016/S1470-2045(00) 00015-2

Pattnaik A, Sarkar R, Sharma A, Yadav KK, Kumar A, Roy P, Mazumder A, Karmakar S, Sen T. 2013. Pharmacological studies on Buchanania lanzan Spreng.-A focus on wound healing with particular reference to anti-biofilm properties. Asian Pacific J. Tropical Biomed. 3, 967-974. https://doi. org/10.1016/S2221-1691(13)60187-2

Pereira MG, Hamerski F, Andrade EF, Scheer ADP, Corazza ML. 2017. Assessment of subcritical propane, ultrasoundassisted and Soxhlet extraction of oil from sweet passion fruit (Passiflora alata Curtis) seeds. J. Supercrit. Fluids 128, 338-348. https://doi.org/10.1016/j.supflu.2017.03.021
Pokorny J, Yanishlieva N, Gordon MH. 2001. Antioxidants in food: practical applications, CRC press. https://doi.org/ 10.1201/9781439823057

Polychniatou V, Tzia C. 2018. Evaluation of surface-active and antioxidant effect of olive oil endogenous compounds on the stabilization of water-in-olive-oil nanoemulsions. Food Chem. 240, 1146-1153. https://doi.org/10.1016/j.foodchem. 2017.08.044

Porra RJ. 2002. The chequered history of the development and use of simultaneous equations for the accurate determination of chlorophylls $a$ and $b$. Photosynth. Res. 73, 149-156. https://doi.org/10.1007/1-4020-3324-9 56

Prance GT, Mori SA. 1979. Lecythidaceae-Part I. The actinomorphic-flowered New World Lecythidaceae (Asteranthos, Gustavia, Grias, Allantoma \& Cariniana). Flora Neotropica Mon. No. 21, $270 \mathrm{pp}$. Notes of anatomical literature and original work on leaf surface (SEM) and petiole anatomy. https://doi.org/10.1086/411902

Puri A, Sahai R, Singh KL, Saxena RP, Tandon JS, Saxena KC. 2000. Immunostimulant activity of dry fruits and plant materials used in indian traditional medical system for mothers after child birth and invalids. J. Ethnopharmacol. 71, 89-92. https://doi.org/10.1016/s0378-8741(99)00181-6

Radice M, Viafara D, Neill D, Asanza M, Sacchetti G, Guerrini A, Maietti S. 2014. Chemical characterization and antioxidant activity of Amazonian (Ecuador) Caryodendron orinocense Karst. and Bactris gasipaes Kunth seed oils. J. Oleo Sci. 63, 1243-50. https://doi. org/10.5650/jos.ess 14007

Ramos AS, Souza RO, Boleti APDA, Bruginski ER, Lima ES, Campos FR, Machado MB. 2015. Chemical characterization and antioxidant capacity of the araca-pera (Psidium acutangulum): An exotic Amazon fruit. Food Res. Int. 75, 315-327. https://doi.org/10.1016/j.foodres.2015.06.026

Ribeiro S, Barbosa L, Queiroz J, Knödler M, Schieber A. 2008. Phenolic compounds and antioxidant capacity of Brazilian mango (Mangifera indica L.) varieties. Food Chem. 110, 620-626. https://doi.org/10.1016/j.foodchem. 2008.02.067

Rocha Ribeiro SM, Queiroz JH, Lopes Ribeiro De Queiroz ME, Campos FM, Pinheiro Sant'ana HM. 2007. Antioxidant in Mango (Mangifera indica L.) Pulp. Plant Foods for Human Nutrition, 62, 13-17. https://doi.org/10.1007/ s11130-006-0035-3

Shailasree S, Ruma K, Prakash HS. 2012. Curative properties of Buchanania lanzan: As evaluated by its anti-oxidant, anti-inflammatory and DNA protective properties. J. Nat. Pharm. 3, 71

Singleton VL, Orthofer R, Lamuela-Raventós RM. 1999. Analysis of total phenols and other oxidation substrates and antioxidants by means of folin-ciocalteu reagent. Methods Enzymol. 299, 152-178. https://doi.org/10.1016/ S0076-6879(99)99017-1

Srdić-Rajić T, Konić Ristić A. 2016. Antioxidants: Role on Health and Prevention. Encyclopedia of Food and Health. Oxford: Academic Press. https://doi.org/10.1016/ B978-0-12-384947-2.00038-6

Tanilgan K, Özcanb MM, Ünverb A. 2007. Physical and chemical characteristics of five Turkish olive (Olea europea L.) varieties and their oils. Grasas Aceites 58, 142-147. https:// doi.org/10.3989/gya.2007.v58.i2.78

Thaipong K, Boonprakob U, Crosby K, Cisneros-Zevallos L, Hawkins Byrne D. 2006. Comparison of ABTS, DPPH, FRAP, and ORAC assays for estimating antioxidant activity from guava fruit extracts. J. Food Comp. Anal. 19, 669-675. https://doi.org/10.1016/j.jfca.2006.01.003 